\title{
IMPORTATION OF IDEOLOGIES: FROM MACAULAY MINUTES TO WOOD COMMISSION
}

Lava Deo Awasthi*

Abstract

In this article I examine

Nepal's language policy with particular reference to Nepal National Education

Planning Commission (NNEPC known as Wood Commission) Report of 1956. In this essay I analyze how the Wood Commission Report was employed as a means of importing values introduced by the British India's Macaulay Minutes of 1835 . I explore how the post independence Education Commission had an overarching effect on the educational language policy

discourse in the country. I investigate the effects of the

NNEPC language policy on the educational practices in Nepal. First, I consider how the independent Nepal responded to the aspirations of the people for change in its educational language planning and policy.

\section{Aspirations for Change}

Nepal witnessed a formal introduction of a Governmental language policy after the inception of democracy in the country in 1951 (Gupta, 1964; NNEPC, 1956). In the 1950s, following the political change, educational programmes became a major concern for the public (Sharma, 1986). The new democratic Government was bound to respond to people's aspirations in the changed context (Caddell, 2002; Gupta, 1964). Schools and educational institutions started to grow rapidly. People's interest in and access to education increased all over the country (Sharma, 1986). People started exerting pressure on the Government to do more to augment the process of reform in education (Gupta, 1964). People's aspiration led the Government to initiate the educational reform programme to respond to country's educational needs (Sharma, 1986).

To bring about a visible change in the country, the Government created the Ministry of Education, and appointed a Secretary of Education and a Chief Inspector of Schools (Eagle, 2000). In order to provide an efficient management base to the school system, Nepal was divided into seven inspectorate zones. Each zone was headed by a Divisional Inspector of Schools. To bring in uniformity in the operation of schools, Educational Administrative Guidelines were developed for the school inspectors (Sharma, 1986).

To obtain advice on education and facilitate the process of change, the Government formed a twenty-member National Education Board (NEB) in 1952 (Sharma, 1986, p. 181). The main tasks of the Board were to "supervise and expand the existing educational facilities" (NNEPC, 1956, p. 1). The NEB played an important role in providing inputs for policy decisions in the changed context. In 1953, the NEB suggested that the Government form a National Commission for Educational Planning to develop a scheme for the universalization of education in Nepal. It also set the agenda for 
the Commission to develop "a uniform system of education for the whole country [emphasis added" (NNEPC, 1956). This reveals that the new democratic Government was also trying to homogenize the peoples in the country by introducing a 'uniform system of education'. From this it appears that although the Government was making changes to comply with the popular demand, in reality it was longing to continue the legacy of the Rana regime (Awasthi, 2004; Gupta, 1964; Caddell, 2002).

\section{Formation of the NNEPC}

In line with the recommendation of the NEB, an Education Commission was formed (Sharma, 1986; Caddell, 2002). In order to accomplish this task, the Government invited foreign advisors (Eagle, 2000; NNEPC, 1956). This was, perhaps, the start of foreign advisor's visible presence in Nepal (Sharma, 1986). Consequently, the country entered into another phase of domination and importation of alien thoughts. Nepal experienced imposition of western values and ideas (Rana, 1998). Intellectually, Nepal became more dependent on the West than it was ever before (Sharma, 1986). The western influence eventually inspired Nepal to attempt to become a monolingual nation-state (NNEPC, 1956). Thus, Nepalese people's desire for change was greeted with an attempt to reduce Nepal's multilingual social construct.

Since the leaderships in the Government, apparently, did not have adequate experience to embark on a new phase of educational reconstruction, they strongly felt a need for technical support from outside Nepal. There was a visible lack of clarity and confidence at the policy level (NNEPC, 1956). Realizing the need for assistance, the United States of America offered technical advice to the Government of Nepal for educational development (Eagle, 2000, p. 19). At that time, Dr Hugh B. Wood, US Fulbright Scholar and educationalist, was on an assignment in India. The Government of Nepal approached the US AID to provide Dr Wood as an education advisor to Nepal. The US Government amiably accepted it, and Dr Wood took his assignment in Nepal in 1953 (Sharma, 1986, p. 181-182). Dr Wood's arrival in Kathmandu heralded the beginning of a new era in educational language policy in the country. It was a turning point in the history of language planning in multilingual Nepal (NNEPC, 1956; Caddell, 2002; Eagle, 2000).

Following the visit of Dr Wood, the Government constituted the Nepal National Education Planning Commission (NNEPC), popularly known as the Wood Commission, in 1954 (Sharma, 1986). Dr Wood was appointed as the Educational Advisor to the Commission.

The Wood Commission was historic and had overarching influence on the language policies in the post-NNEPC Nepal. It was historic in the sense that such a Commission was formed for the first time in the country, and that it still forms the basis for Nepal's contemporary educational policy. The NNEPC report has been influential in the education system and educational language policies introduced at different points in time (Caddell, 2002). Moreover, the NNEPC legacy is still in action and has been playing a role in the construction, deconstruction and reconstruction of Nepal's language policy (NEC, 1992).

More importantly, the NNEPC report is a pioneering piece of work in the field of education in the country. It set the tone of the entire education sector. It was acclaimed for its comprehensive coverage and detailed description of the issues on education. It was seen as a step forward in the Nepalese education system (NNEPC, 1956). The Commission placed emphasis on the universalization of primary education and on the improvement of educational service delivery systems across the country. The report acknowledged the role of education for social transformation and decentralization (Caddell, 2002). In this respect, the report was a landmark in the history of Nepalese Education (NNEPC, 1956). Besides, the Commission 
tried to highlight the life of rural Nepal. It made an attempt to paint a picture of multiethnic, multicultural and multilingual nation. The report looked into the issues relating to the medium of instruction, language teaching and learning, teacher preparation and instructional materials, emphasizing the importance of the non-Nepali speaking (NNS) children in schools of Nepal (NNEPC, 1956).

Nevertheless, the NNEPC report was unable to capture the spirit of the political change in the country. The report, in reality, failed to recognize the need for multilingual education in Nepal. Instead, the report placed emphasis on introducing reduction of multilingualism. It tried to impose linguistic restrictions, and discouraged the spread of multilingualism in the country (Caddell, 2000; Chene, 1996).

\section{The NNEPC Report: Importation of Western Ideals}

Multilingualism has been people's lifeline in the South Asian Region (Ferguson, 1996). People in Nepal present a living example of multilingual social life. Nepal's diversity has been celebrated for time immemorial. It was celebrated by the Malla Kings. So was by Prithvi Narayan Shah, who unified the country (Acharya, 2002; Rana, 1998; Bhattarai, 2001). Thus, reduction of multilingualism was not an indigenous construct of Nepal. The linguistic restrictionism was an alien concept for the people and polity, and was an importation from the west. The concept of reductionism grew during the British Raj in India, and flourished after the NNEPC report. Dr Wood played a major part to give shape to reduction of multilingualism in this country. The following views expressed by Dr Wood reveal his monolithic mindset. I quote:

[...... that two hundred years before, the very problem had started then in the face in the United States of America, which at that time had a multiplicity of spoken languages: but that after the War of Independence, English was given due prominence as the medium of instruction and that today there is no problem of language (as cited in Caddell, 2000 from a press release quoting Wood).

These remarks made by Dr Wood clearly reflected the non-Nepali ideology of a monolingual nation-state. Since Dr Wood was the architect of the NNEPC, the report, owing to this, proved to be a means of advocating the western ideology of monolingualism. It becomes clear that $\mathrm{Dr}$ Wood's concept of multilingual restrictionism played a decisive role while crafting the report. The NNEPC, thus, was the manifestation of the one-language [ek bhasa] non-Nepali construct. The report itself was an example of how an alien ideology was imported to transform Nepal into a monolingual nation-state (Caddell, 2000; Chene, 1996).

\section{The Macaulay Minutes}

Nepal's educational language policies are heavily influenced by the language polices of the British India. The Macaulay Minutes ${ }^{1}$ on Education of 1835 during the British raj in India greatly affected Nepal's educational policies (Sharma, 1986). Stating the intent of the Macaulay Minutes, Phillipson (1992, p. 110) notes that "The significance of language was understood from the early expansionist phase of imperialism. [...] the English language was regarded as a force for the 'modernizing' of the country [India], the purpose being to educate a class of Indians who could function as interpreters between the British colonial power and the millions of Indians they 1 The British Government in India invited Lord Macaulay from Britain in 1835 to decide about the medium of instruction and set the structure of education. Macaulay was Chairman of the Governor-General's Committee on Public Instruction (Phillipson, 1992). The Macaulay Minutes are considered to be the foundation of Indian education system. Lord Macaulay introduced English as the medium of instruction. He, however, is often blamed for imposing the English education system and the language of the colonials. More serious charge on Macaulay is that he introduced the Downward Filtration Model of education to anglicize the people in India. 
governed, 'a class of persons Indian in blood and colour, but English in taste, in opinions, in morals and in intellect'..."

The underlying meaning of the Macaulay Minutes was thus to create a class of people that could serve the purpose of the East India Company and that could maintain supremacy of the colonial power over the native speakers of Indian languages by imposing the English language, and its values and principles. The Macaulay Minutes provided India with a basis for introducing the modern education system in place of indigenous Indian education (Prasad, 2001).

The hidden agenda of the Macaulay Minutes was to gradually Anglicize India and dislodge Indian linguistic culture (Knapp, 2002) and implement English curricula across India. The Minutes formally opened ways for the expansion of the English language in India both as the medium of introduction and as a subject of study (Cha, 2002). Also, the agenda for the change in India through the Macaulay Minutes was to divide India linguistically between Anglophile elites and the masses. For this, Macaulay employed the 'downward filtration method' by making the local elite an agent for anglicizing India (Knapp, 2002).

Phillipson (1992) observes that the result of the Macaulay Minutes was that throughout the South Asian sub-continent [including Nepal] English became the medium of all formal domains of a society's functioning including education, administration, trade and commence. Because of Nepal's cultural, religious and social ties, and educational links with India, the effect of the Macaulay Minutes was far-reaching on the minds and lives of the people in Nepal.

Owing to the effects of the Macaulay Minutes, people started ignoring the indigenous languages and education systems in the Sub-continent (Reagan, 1996). Consequently, the roots of Hindu and Buddhist traditions of education in Nepal were badly shaken by the language policy that followed the Macaulay Minutes. Further, the educational policy in India had visible impacts on Nepal's education system and its language policies.

There are inter-connections between the Macaulay Minutes and the Wood Commission (NNEPC) report. The effects of the Macaulay Minutes are clearly seen in NNEPC findings and recommendations.

Nepal's Educational Language Policy: Continuation of Colonial Legacy

We can see a link between what Lord Macaulay said in India and what the Wood Commission (NNEPC) suggested in Nepal. There are striking similarities between the two. I have taken some examples from both the Macaulay Minutes and Wood Commission. I have arranged them into five broad categories in which they have common views and approaches. Under each category I have supplied sub-headings summing up the substance of the text under each column. I have also italicised the key words and phrases of the extracts in order to help see the similarities between the two. My major categories are:

Assimilation: Assimilation of people/s into the language and culture of the rulers

Destruction: Systematic destruction of native languages and cultures

Perpetuation: Use of propaganda and misuse of state machinery to perpetuate language power

Possession: Monopoly over the access to intellectual wealth

Restriction: Control over printing and production of materials

Similarities in these categories reveal that the Macaulay Minutes and Wood Commission have followed the western-style monolingual model. They resemble and have many things in common in this respect. Below are the extracts: 


\begin{tabular}{|c|c|}
\hline $\begin{array}{c}\text { THE MACAULAY MINUTES OF } \\
\text { THE BRITISH INDIA }\end{array}$ & $\begin{array}{c}\text { THE WOOD COMMISSION OF } \\
\text { NEPAL }\end{array}$ \\
\hline \multicolumn{2}{|r|}{ Assimilation } \\
\hline $\begin{array}{l}\text { Downward filtration: } \\
\text { "We must at present do our best to } \\
\text { form a class who may be interpreters } \\
\text { between us and the millions whom } \\
\text { we govern; a class of persons, Indian } \\
\text { in blood and colour, but English in } \\
\text { taste, in opinions, in morals, and in } \\
\text { intellect" (Macaulay in Edwards, } \\
1967 \text {, p. 4) } \\
\text { "It is possible to make natives of } \\
\text { this country thoroughly good English } \\
\text { scholars, and that to this end our } \\
\text { efforts ought be directed" (Macaulay } \\
\text { in Edwards, 1967: 4) } \\
\text { "...the natives are desirous to be } \\
\text { taught English, and are not desirous } \\
\text { to be taught Sanskrit or Arabic; ..." } \\
\text { (Macaulay in Edwards, 1967) }\end{array}$ & 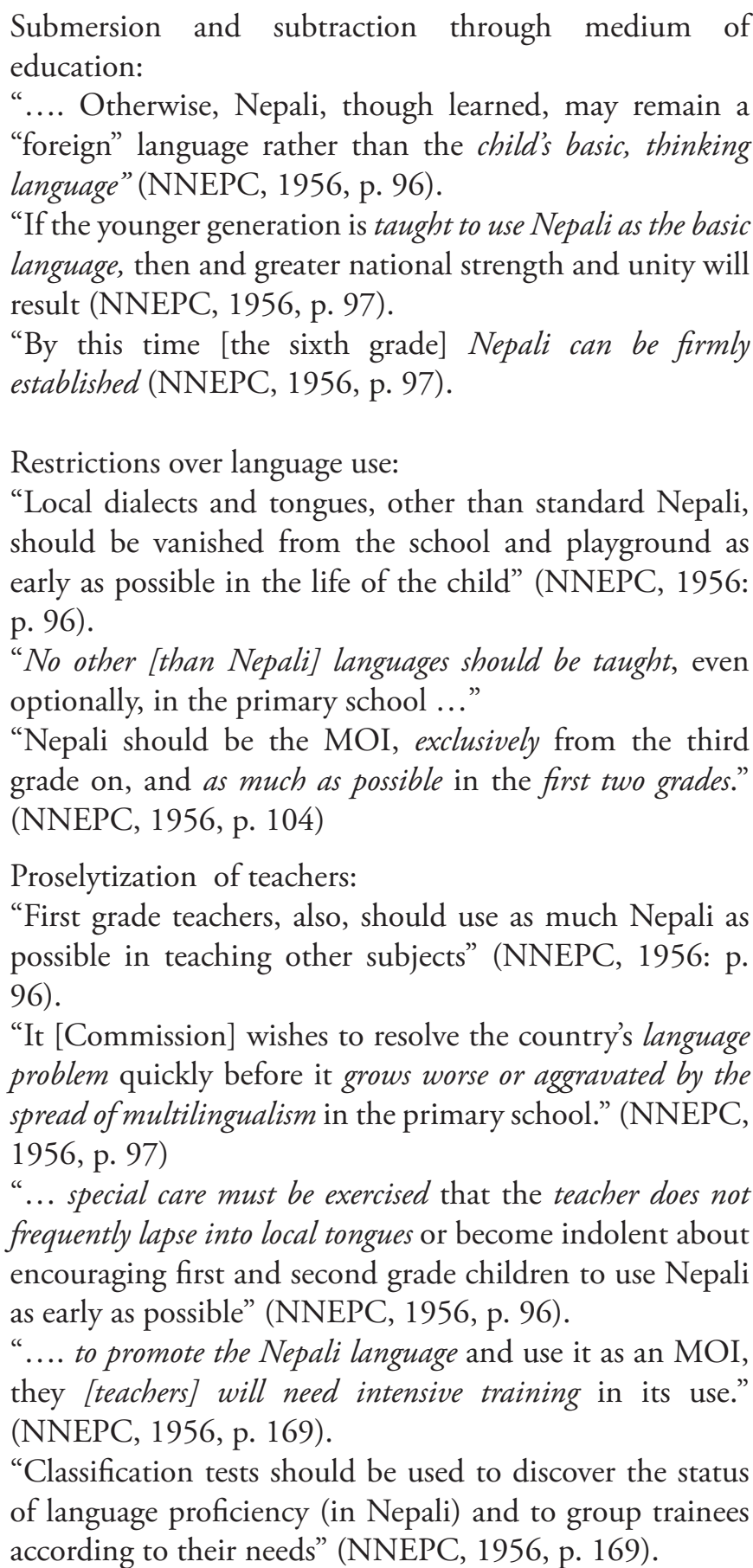 \\
\hline
\end{tabular}




\section{Destruction}

Conversion:

"It is my firm belief that if our plans of education are followed up, there will not be a single idolater among the respected classes 30 years hence" (Macaulay in his letter to his father dated $12^{\text {th }}$ Oct, 1836 as cited in V Ravi Kumar).
Homogenization:

"It is believed that many pupils will cease to be dependent upon their MT[...]. And it should be emphasized that if Nepali is to become the true national language, then we must insist that its use be enforced in the primary school" (NNEPC, 1956, p. 96).

\section{Perpetuation}

Linguistic Rejectionism:

"I have never found one among them [Orientalists] who could deny that a single shelf of a good European library was worth the whole native literature of India and Arabia" (Macaulay in Edwards, 1967: p. 1) "The funds which thus be placed at our disposal would enable us to give larger encouragement to ... schools in which the English language might be well and thoroughly taught. (Macaulay in Edwards, 1967 , p. 4)

"... we ought to employ them [funds] in teaching what is best worth knowing; that English is better worth knowing than Sanskrit and Arabic..." (Macaulay in Edwards, 1967, p. 4)
Imposition:

"And it should be emphasized that if Nepali is to become the true national language, then we must insist that its use be enforced in the primary school" (NNEPC, 1956, p. 96).

\section{Possession}

Intellectual supremacy:

"Whoever knows that language [English], has access to all the vast intellectual wealth, which all the wisest nations of the earth have created and hoarded in the course of ninety generations" (Macaulay in Edwards, 1967, p. 2)

"We know that foreigners of all nations do learn our language [English] sufficiently to have access to all the most abstruse knowledge which it contains, ..." (Macaulay in Edwards, 1967, p. 3)

"We have to educate a people who cannot at present be educated by means of their mother-tongue. ... the English tongue is that which would be the most useful to our native subjects [Indians]" (Macaulay in Edwards, 1967, p. 2)
Control over knowledge and information: ".... They [native languages] would hinder the teaching of Nepali, ... time is needed for other more important and fundamental learning, ..." (NNEPC, 1956, p. 104)

"The Commission believes that ... the techniques of reading and writing should be developed only in Nepali. (NNEPC, 1956, p. 96)

"If we accept the goal of mass education, such extravagance [inclusion of additional languages] cannot be justified on any ground. (NNEPC, 1956, p. 97) 


\begin{tabular}{|l|l|}
\hline \multicolumn{2}{|c|}{ Restriction } \\
\hline $\begin{array}{l}\text { Prohibition for printing: } \\
\text { "I would at once stop the printing of Arabic and }\end{array}$ & $\begin{array}{l}\text { Control over Material: } \\
\text { "..... printed and manufactured aids must }\end{array}$ \\
Sanskrit books; ........ We are a Board for wasting & $\begin{array}{l}\text { be produced in the Nepali language, and be } \\
\text { designed for Nepal's schools" (NNEPC, 1956, }\end{array}$ \\
$\begin{array}{l}\text { public money, for printing books which are less } \\
\text { value than the paper on which they are printed }\end{array}$ & $\begin{array}{l}\text { p. 186). } \\
\text { was while it was blank; " (Macaulay in Edwards, }\end{array}$ \\
$\begin{array}{ll}1967, \text { p. 4) } & \end{array}$ \\
\hline
\end{tabular}

From these examples it becomes clear that both the Macaulay Minutes and Wood Commission had the same mission. They followed the same course of assimilation, destruction, perpetuation, possession and restriction in order to establish a monolingual nation-state. It is not simply a matter of coincidence to have so many things in common. Reduction of multilingualism was the manifestation of their mission. Both of these pioneering pieces are the reflections of the underlying agenda borrowed from the west. Macaulay tried to achieve the purpose of anglicizing India by employing the 'downward filtration model', whereas the NNEPC attempted to expand Nepali through a 'direct prohibition method' under the pretext of national unity. Both of them aim at attaining their objectives through linguistic expansion of the dominant language at the cost of the various mother tongues i.e. a subtractive spread ${ }^{2}$ of one language (SkutnabbKangas, 2000; Yadav, 1990).

\section{Nepalese Factors Influencing NNEPC Report}

It is evident that the underlying principle of the NNEPC report was to turn Nepal into a monolingual nation-state. It also becomes clear that the report was an attempt to systematically engineer the plan to introduce linguistic nationalism in the country (Rana, 1998). As a result, the agenda for linguistic nationalism (Awasthi, 2004) has received prominence in

2 According to Skutnabb-Kangas (2000) subtractive spread of languages means that incoming language first displaces, then replaces original languages, domain by domain. According to Phillipson (1992) it is a result of linguistic imperialism. the educational language planning throughout the post-independence era of Nepal (Yadav, 1990). It proved to be a benchmark for national development in the country (Whelpton, 1997). The NNEPC legitimized the Nepali language and tried to make Nepali inevitable for all primary school children (Caddell, 2002; Chene, 1996).

It is pertinent to analyze why the Macaulay Minutes became so important in the NNEPC report. Several domestic factors may have contributed to this. One of the factors might be the educational orientation of the Commission members. Most of the members were influenced by the post-Macaulay Minutes India by virtue of their education and training. The Commission members appeared to be honest and were committed to doing well to the children in Nepal. There is no doubt about their good intentions. However, the effects of their work were different from what they intended. Despite being very knowledgeable and highly level senior Government officials and extremely qualified professionals, from the results of the report it appears that they happened to be the carriers of the colonial culture of the British India. It could be claimed that there was a visible effect of 'downward filtration model' on the NNEPC members (Chene, 1996; Caddell, 2002; Awasthi, 2004).

The second factor could be the Macaulay model itself. The Macaulay Minutes might have been taken as the prototypic work for educational planning in Nepal. The Commission members might have employed the Minutes as a ready 
reference while preparing the NNEPC report. The third factor might be that the members of the Commission were mainly from the elite social background. Another factor could be that the ordinary people's level of awareness was extremely low. People were unable to challenge the framework set by the Commission. Also, there were no open dialogues between the rulers and the ruled. The Commission members seemed to work in the interest of the former.

\section{NNEPC Implications}

Although Nepal's overt policies on language(s) after the Wood Commission changed from time to time to respond to the political changes in the country, the covert policies appear to have been reproduced and/ or recycled from the NNEPC report. The basic ideology put forward by the Wood Commission has still been seen as a framework for educational language planning in the country (Awasthi, 2004; Caddell, 2000, 2002; Yadav, 1990).

More importantly, the NNEPC Report overshadowed the work of the education Commissions that were formed at different points in time after 1956 (ARNEC, 1960; NESP, 1971; NEC, 1992; NLPRC, 1993; HLNEC, 1998). They followed the pattern that was laid down by the Wood Commission. Although Nepal witnessed legislative changes in its educational language policies after 1990, the practices in the country have remained unchanged (EDSC, 1997; EDSC, 1999; CHIRAG, 2001; VCDP, 2004).

Although the mission of the Wood Commission appears to be guided by the aspirations of the people as to how all children in this country could receive good education according to the spirit of democracy, the effect of the Wood Commission report was such that it disadvantaged the indigenous and ethnic minority children. The report appeared to be an assimilation-oriented majority discourse' in the sense that it tried to legitimize Nepali-only medium of instruction policies. It demonstrated deficiency orientations and presented Nepal's minority languages as problems, not as rights and resources (Ruiz, 1984; Kontra et al., 1999).

\section{Summing $U_{p}$}

The Wood Commission report failed to represent 'real' Nepal and failed to recognize the importance of children's mother tongue in education. It tried to legitimize the Nepali-only ideology and contributed to promoting this concept in the school system. The report is a testimony of how a state tends to become triumphalist over the minorities and tries to homogenize the indigenous peoples in the country. The report states that:

The study of a non-Nepali local tongue would mitigate against the effective development of Nepali, for the student would make greater use of it than Nepali - at home and in the community - and thus Nepali would remain a "foreign" language. If the younger generation is taught to use Nepali as the basic language, then other languages will gradually disappear, and greater national strength and unity will result (NNEPC - 1956, p. 97).

In contrast, if we look at the Report of the UNESCO Meeting of Specialists 1951, it highlights the importance of mother tongue, and shows interdependence of mother tongue and second language. The report (UNESCO, 1951) illuminates that:

[....] it seems clear that national interests are best served by optimum advancement of education, and this in turn can be promoted by the use of the local language as a medium of instruction, at least at the beginning of the school programme.

[....] an equal or better command of the second language can be imparted 
if the school begins with the mother tongue as the medium of instruction, subsequently introducing the second language as a subject of instruction.

The UNESCO Report emphasized the need for mother tongues to ensure national unity and to promote the second language. By contrast, the NNEPC placed emphasis on the development of the Nepali language at the cost of other nonNepali tongues. It insisted that 'greater national strength and unity' would be achieved by adopting Nepali as 'the basic language' in the school system and thereby making other languages disappear.

Further, Chene (1996) raises the question about the intention of the NNEPC. She holds that the Commission's policy of Nepali as the medium of instruction in schools was a measure that would actively work to kill off the other languages of the country (1996, p. 126). From her observation also it appears that the Commission took 'other languages' as a threat to the Nepali-nation and national unity.

The NNEPC seems to see local languages as an obstacle to education. This argument is against the very foundation of the Nepali-nation (Awasthi, 2004) and against the principles of education (UNESCO, 1951; UNESCO, 2003; OSCE, 1992; Dutcher, 1995, p. 36). Clearly, Nepal as a nation-state rests on its multicultural, multiethnic and multilingual construction. It is also clear that Nepal's geography, ecology, demography and social construction, inter alia, are all in harmony with multilingualism. Nepal's diversity is its reality. If its linguistic diversity is reduced and/ or restricted, the existence of Nepal is unthinkable. Skutnabb-Kangas emphasizes that "national unity can only be built on respect for the languages and cultures of all the peoples who make up the nation" (2000, p. 241). Thus, the NNEPC's proposition is unfounded and chauvinistic. It is detrimental to providing a firm foundation for non-Nepali speaking children's education and detrimental to offering a broad base for the Nepali-nation.

\section{References}

Acharya, M. R. (2002). Nepal: Culture Shift! Reinventing Culture in the Himalayan Kingdom. Delhi: Adroit Publishers.

ARNEC (1960). All Round National Education Committee. Kathmandu. Author.

Awasthi, L. D. (2004). Exploring Monolingual School Practices in Multilingual Nepal. PhD Thesis. Danish University of Education, Copenhagen

Bhattarai, G. D. (January 11, 2001). Prithvi Narayan Shah the Great: Architect of Modern Nepal. The Rising Nepal, p. 4.

Caddell, M. (2000). What Education for All? Education, the Nation and Development in Nepal. An unpublished paper.

Caddell, M. (2002). 'Outward Looking Eyes': Visions of Schooling, Development and the State in Nepal. $\mathrm{Ph}$. D. Thesis. University of Edinburgh.

Cha, M. English Education in India. In http://www. bharatvani.org/general_inbox/pramod/indic_ education.html 4/6/02.

Chene, M. D. (1996). Ethnography in the Janajati-yug: Lessons from Reading Rodhi and other Tamu Writings. Studies in Nepali History and Society, Vol.1, No.1, June, 97-162.

CHIRAG (2001). Bilingual Education A Study Report. Kathmandu: Author.

Dutcher, N. (1995). The Use of first and second languages in education: A review of international experience. Pacific Island Discussion Paper Series, World Bank.

Eagle, S. (2000). The Language Situation in Nepal. In R. B. Baldauf Jr. and R. B. Kaplan (Eds.) Language Planning in Nepal, Taiwan and Sweden, 4-59. Clevedon: Multilingual Matters Ltd.

Educational and Developmental Service Centre (1997). National Achievement Level of Grade 3 Students. Kathmandu: Author.

Educational and Developmental Service Centre (1999). National Assessment of Grade 5 Students. Kathmandu: Author.

Edwards, M. (1967). British India 1772 - 1947. New Delhi: Rupa Press. In http://www.swaraj.org/ shikshantar/resources_macaulay.html 4/6/02

Ferguson, C. A. (1996). South Asia as a Sociolinguistic Area. In Thom Huebner (ed.). Sociolinguistic Perspectives: Papers on Language in Society, 19591994. Oxford: Oxford University Press. 
Fishman, J. A. (1968). Summary: UNESCO Meeting of Specialists, 1951. In Joshua A. Fishman (Ed.). Readings in the Sociology of Language. The Hague: Mouton.

Gupta, A. (1964). Politics in Nepal: A study of Post-Rana Political Development and Party Politics. Bombay: Allied Publishers.

HLNEC (1998). High Level National Education Commission Report. Kathmandu: Nepal.

Knapp, S. In http://www.stephenknapp.com/uncovering_the_ truth_about_India's_history,htm 4/6/02

Kontra, M., Phillipson, R., Skutnabb-Kangas, T. and Varady, T. (1999). Conceptualising and Implementing Linguistic Human Rights. In M. Kontra, R. Phillipson, T. Skutnabb-Kangas, and T. Varady (Eds.). Language: A Right and a Resource Approaching Linguistic Human Rights, 1-24. Budapest: Central European University Press.

NEC (1992). National Education Commission Report. National Education Commission. Kathmandu: Nepal.

NESP (1971). National Education System Plan (19711975). Kathmandu: Ministry of Education, HMG/ Nepal.

NLPRC (1993). Rastriyabhasa neetisujhab aayogkopratibedan [National Languages Policy Recommendation Commission Report. Kathamandu: Royal Nepal Academy, Kathmandu.

NNEPC (1956). Education in Nepal: Report of the Nepal National Educational Planning Commission. Kathmandu: Bureau of Publications, College of Education.

OSCE (1992). High Commissioner on National Minorities: The Hague Recommendations Regarding the Education Rights on National Minorities and Explanatory Note: http://www.osce.org/

Phillipson, R. (1992). Linguistic Imperialism. Oxford: Oxford University Press.
Prasad, C. (2001). The Impure milk of Lord Macaulay? In http://www.ambedkar.org/chandrabhan/ Theimpure.htm 4/6/02.

Rana, P. S. J. B. (1998). The History of Nepal. In P. S. J. B. Rana and D. N. Dhungel (Eds.). Contemporary Nepal, 14-41. New Delhi: Vikas publishing House.

Reagan, T. (1996). Non-Western Educational Traditions: Alternative Approaches to Educational Thought and Practice. Mahwah: Lawrence Erlbaum Associates.

Ruiz, R. (1984). Orientations in Language Planning. Journal of the National Association for Bilingual Education. Vol. 8, No. 2, Winter, 15-34

Sharma, G. (1986). Nepalma shikshako itihaas, 2043 BS. [History of Education in Nepal]. Kathmandu: Samjhana Press.

Skutnabb-Kangas, T. (2000). Linguistic Genocide in Education or Worldwide Diversity and Human Rights? Mahwah: Lawrence Erlbaum Associates..

UNESCO (1951). The Use of Vernacular Languages in Education: The Report of the UNESCO Meeting of Specialists, 1951. In J. A. Fishman (Ed.). Readings in the Sociology of Language, 688-716. The Hague: Mouton \& Co. N.V. Publishers.

UNESCO (2003). Education in a Multilingual World. UNESCO Position Paper.

VCDP (2004). Vulnerable Community Development Plan: Education for All 2004-2009. Kathmandu: Ministry of Education and Sports.

Whelpton, J. (1997). Political Identity in Nepal: State, Nation, and Community. In D. N. Gellner, J. Pfaff-Czarnecka, and J. Whelpton (Eds.). Nationalism and ethnicity in a Hindu Kingdom: The politics of culture in contemporary Nepal, 39-78. Amsterdam: Hardwood Academic Publishers.

Yadav, S. K. (1990). Language Planning in Nepal: An Assessment and Proposal for Reform. PhD Thesis, University of Rajasthan. 